\title{
Poemas de Manuel Pachón
}

\section{Inventario de la parca}

La orquídea transparente en cuanto besa el aire se marchita.

El urapán, con su nombre de gigante ancestral roído por la sierra se hace leña.

La ballena de danza y voz azul agoniza varada en sucias playas.

El colibrí, intenso parpadeo, en extinción.

El jaguar, sol y sombra al acecho, muerto.

El cóndor, muerto.

El pingüino, extinguido.

El río pululante de vida pasa por la ciudad y continúa arrastrando su cadáver para pudrir el mar.

Sólo el hombre, oscuro e infeccioso entre sus ratas, prolifera.

\section{Utopía en azul}

Me sumergí y nadé desenfrenadamente en una piscina repleta de tornillos y tuercas.

Rompí mis dientes.

Las espirales afiladas arrancaron mis cabellos.

Las uñas de mis manos y pies sangran quebradas de tanto chocar con el acero.

El aceite mecánico ha dejado en $\mathrm{mi}$ boca su sabor viscoso.

Salgo a la superficie y ahí están las hojas y las flores de nuevo, los pájaros no se habían ido, bajo mis pies el musgo y muy cerca el murmullo del río.

\section{Canto por la recuperación} de una laguna

¡Qué alegría volver a ver tu rostro hoja de luz!

Laguna sagrada de Tibabuyes, madre de los niños de oro, vientre de agua...

Saludo tu manera de repetir el cielo, de multiplicar en láminas la caída del sol y permitir que el viento te acaricie rizándote la piel.

La diosa Sie se nutre de tus aguas, habita, juega, duerme dentro de ti y aguarda con abrazo mortal al que no te respeta.

Has despertado para recordarnos que aún somos criaturas del agua.

Tu presencia serena nos refresca y nos hace pensar que se romperá la profecía y no pagaremos con monedas de sangre el precio de la sed.

\section{Agua}

Te amo en tu liquidez de fruta acrisolada.

Cuando te acercas bebo de tu cuerpo fundido de manzana y siento transcurrir una fresca sustancia de azúcar arcoiris y alma.

Tu movimiento de río de chorro lento

de cascada

despierta en mí

corrientes

en busca de tu mapa.

¡Oh niña refrescante, te quiero dulce y clara!

\section{Poema de agua}

(Bolero aguamarina)

Este poema te sonará como agua.

Lo sentirás correr en su lecho de palabras.

Y entre la música mojada de esta corriente clara, hallarás una botellaproveniente del mar de mi mirada.

Allí un papel te dice que estoy aquí, en el lavadero de tu casa, esperando que caigas a la alberca para ahogar en tu carne esta añoranza. 